\title{
First record and DNA barcode of the clearwing moth Tinthia tineiformis (Esper, 1789) from Malta, central Mediterranean
}

\author{
Clare Marie Mifsud ${ }^{1,2}$, Denis Magro ${ }^{2}$, Adriana Vella ${ }^{1,2}$ \\ 1 Conservation Biology Research Group, Biology Department, University of Malta, Msida, MSD 2080, Malta. 2 Biological Conservation Research \\ Foundation, PO BOX 30, Hamrun, HMR 1000, Malta. \\ Corresponding author: Adriana Vella, adriana.vella@um.edu.mt
}

\begin{abstract}
A sesiid species, Tinthia tineiformis (Esper, 1789), is reported for the first time from the Maltese Islands, central Mediterranean. This new record represents the first species belonging to the subfamily Tinthiinae in Malta. The specimen was identified through morphological and genetic analyses. Observations of the live specimen revealed the use of jumping strategies by this species.
\end{abstract}

\section{Keywords}

Biodiversity conservation, Lepidoptera, Maltese Archipelago, Sesiidae.

Academic editor: Ivan N. Bolotov | Received 19 April 2019 | Accepted 3 July 2019 | Published 2 August 2019

Citation: Mifsud CM, Magro D, Vella A (2019) First record and DNA barcode of the clearwing moth Tinthia tineiformis (Esper, 1789) from Malta, central Mediterranean. Check List 15 (4): 595-599. https://doi.org/10.15560/15.4.595

\section{Introduction}

Clearwing moths, Sesiidae, exhibit Batesian mimicry and usually mimic hymenopterans in their morphology and in some cases also in their behavior (Skowron et al. 2015; Skowron Volponi et al. 2018). Sesiid moths are morphologically readily distinguished from other moth families by the presence of transparent areas on their wings due to the lack of scales and the presence of a hair tuft at the tip of the abdomen (Laštůvka and Laštůvka 2001). Sesiid moths have been classified into two subfamilies, Sesiinae and Tinthiinae (Naumann 1971; Laštůvka and Laštůvka 2001), although some authors recognise a third subfamily, Paranthreninae (Duckworth and Eichlin 1974; Heppner and Duckworth 1981; McKern et al. 2008). The subfamilies Tinthiinae and Sesiinae are distinguished by the morphology of the antennae. Tinthiinae do not possess clavate antennae and possess either filiform or setiform antennae (Duckworth and Eichlin 1974; Laštůvka and Laštůvka 2001; Paolucci 2016).
The larvae of clearwing moths are generally monophagous or oligophagous being associated with a specific host plant species or a plant family and are rarely polyphagous (Špatenka et al. 1999; Laštůvka and Laštůvka 2001; Bella et al. 2017). The endophagous larvae are usually univoltine and require one year for development inside stems or roots of herbaceous or woody plants (Duckworth and Eichlin 1974; Karimpour et al. 2007; Gorbunov and Efetov 2018). Rhizophagous species in contrast to xylophagous species are generally more restricted to a few locations as they do not disperse far from their host plant (Garrevoet et al. 2007; Bąkowski and Hołowiński 2010; Bąkowski et al. 2010). Sesiid moths have also been described as colonial, where colonies are usually located upon a few individual host plants (Garrevoet et al. 2005; Paolucci 2016). These habitual characteristics make it generally difficult to observe and capture sesiid moths without the use of species-specific pheromone lures (Naka et al. 2008; Levi-Zada et al. 2011). 


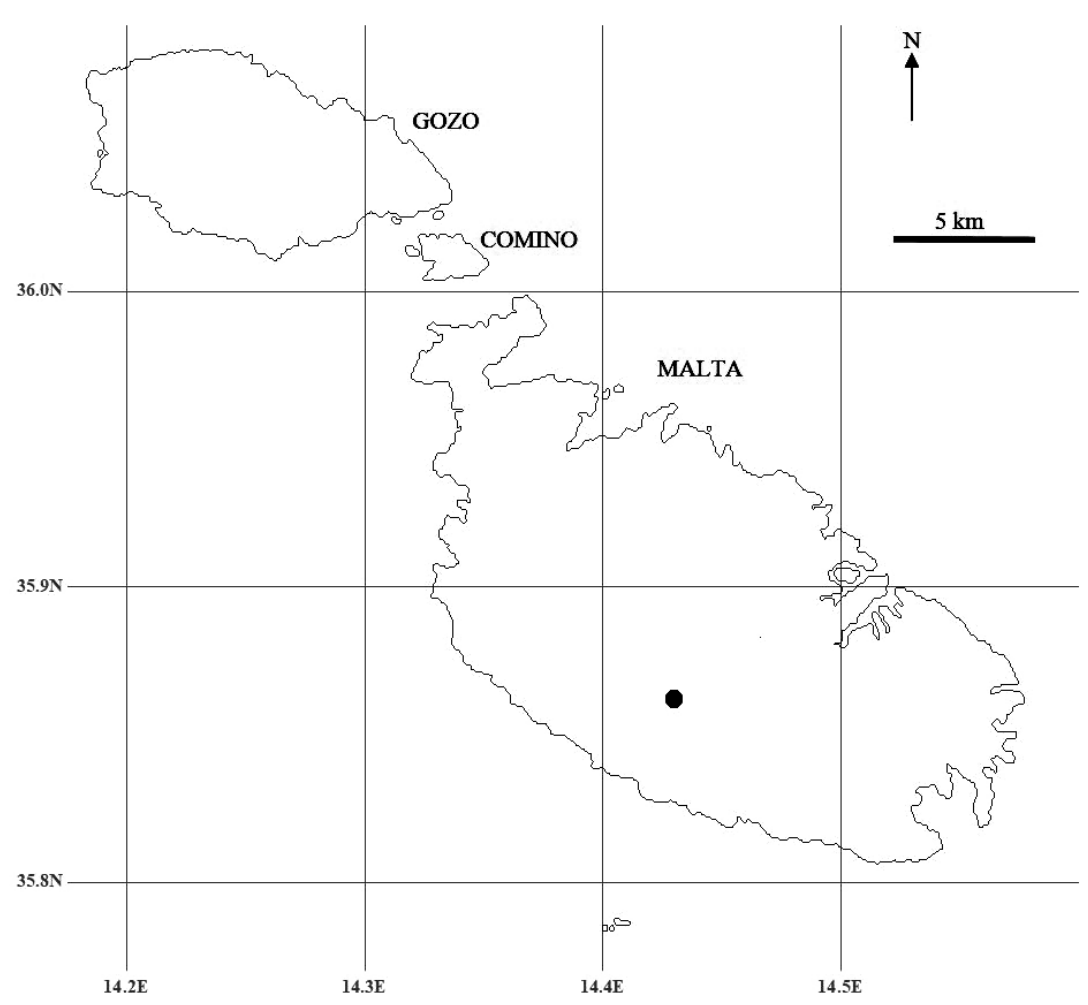

Figure 1. Map of the Maltese Islands, central Mediterranean and the geographical location of the collection site (black dot) for the first record of Tinthia tineiformis from Siggiewi, Malta.

From the Palaearctic region, 347 sesiid species have been listed in the most recent global checklist (Kallies and Pühringer 2004). The Maltese Islands are known to host four sesiid species (Karsholt and Nieukerken 2013), i.e. Synanthedon myopaeformis (Borkhausen, 1789), Bembecia tunetana (Le Cerf, 1920), Chamaesphecia aerifrons (Zeller, 1847), and C. anthraciformis (Rambur, 1832), all belonging to the subfamily Sesiinae, tribe Synanthedonini. In this paper, we report an additional sesiid species to the Maltese entomofauna, Tinthia tineiformis (Esper, 1789), which we identified using morphological features and confirmed by means of the DNA barcoding approach. Our discovery represents the first record of the subfamily Tinthiinae in Malta. Tinthia tineiformis is a Holo-Mediterranean species that occurs in southern Europe including the Iberian, Apennine, and Balkan peninsulas, France, major Mediterranean islands including Sicily, Sardinia, Corsica, and Crete; it is also recorded from Asia Minor, the Middle East, and northern Africa (Laštůvka 1985; Špatenka et al. 1999; Laštůvka and Laštůvka 2001; Karsholt and Nieukerken 2013; Bella et al. 2017).

\section{Methods}

Ongoing biodiversity field research and monitoring undertaken by us in the Maltese Islands has allowed both the collection of dead and live insects. The individual specimen described here was collected from a limestone rubble wall surface in Siggiewi, Malta, central Mediterranean (Fig. 1). The geographical coordinates were obtained using Google Earth ${ }^{\circledR}$ v. 7.3.2 (geodetic datum: WGS84; map data: 2017-9-17, Google, DigitalGlobe). The live specimen was kept in a large enclosure indoors for behavioral observations, after which it was pinned for detailed morphological study and photography (Fig. 2). Morphological identification of the specimen was based on Duckworth and Eichlin (1974), Heppner and Duckworth (1981), Laštůvka (1985), Laštůvka and Laštůvka (2001), and Paolucci (2016). The pinned voucher specimen is deposited in the wild species collection of the Conservation Biology Research Group, University of Malta (CBRG-UM), Msida, Malta. Two legs were stored in absolute ethanol at $-20^{\circ} \mathrm{C}$ as tissue vouchers for molecular analyses at CBRG-UM.

A total DNA was extracted from a single leg using GF-1 Tissue DNA Extraction Kit (Vivantis, Malaysia). The 658 bp barcode region of the mitochondrial cytochrome $c$ oxidase subunit I (COI) was amplified using standard LepF1/LepR1 primers (Hebert et al. 2004). Three PCR reaction replicates were carried out in $25 \mu \mathrm{L}$ reaction volume containing approximately 10ng DNA template, 1X FIREPOL ${ }^{\circledR}$ Master Mix containing 2.5 $\mathrm{mM} \mathrm{Mg}^{2+}, 200 \mu \mathrm{M}$ of each dNTP and $1 \mathrm{U}^{\text {FIREPOL }}{ }^{\circledR}$ DNA polymerase (Solis BioDyne, Estonia), and $0.5 \mu \mathrm{M}$ of each primer. PCRs were carried out on a Nexus Gradient Mastercycler ${ }^{\circledR}$ (Eppendorf, Germany) using the following temperature profile: $95^{\circ} \mathrm{C}$ for $5 \mathrm{~min}$; followed by 6 cycles of $95^{\circ} \mathrm{C}$ for $45 \mathrm{~s}, 45^{\circ} \mathrm{C}$ for $30 \mathrm{~s}, 72^{\circ} \mathrm{C}$ for $1 \mathrm{~min}$ and 36 cycles of $95^{\circ} \mathrm{C}$ for $45 \mathrm{~s}, 50^{\circ} \mathrm{C}$ for $30 \mathrm{~s}, 72^{\circ} \mathrm{C}$ for 1 min, and a final extension at $72^{\circ} \mathrm{C}$ for $15 \mathrm{~min}$. From each PCR reaction, $2 \mu \mathrm{L}$ of the PCR product was visualised 


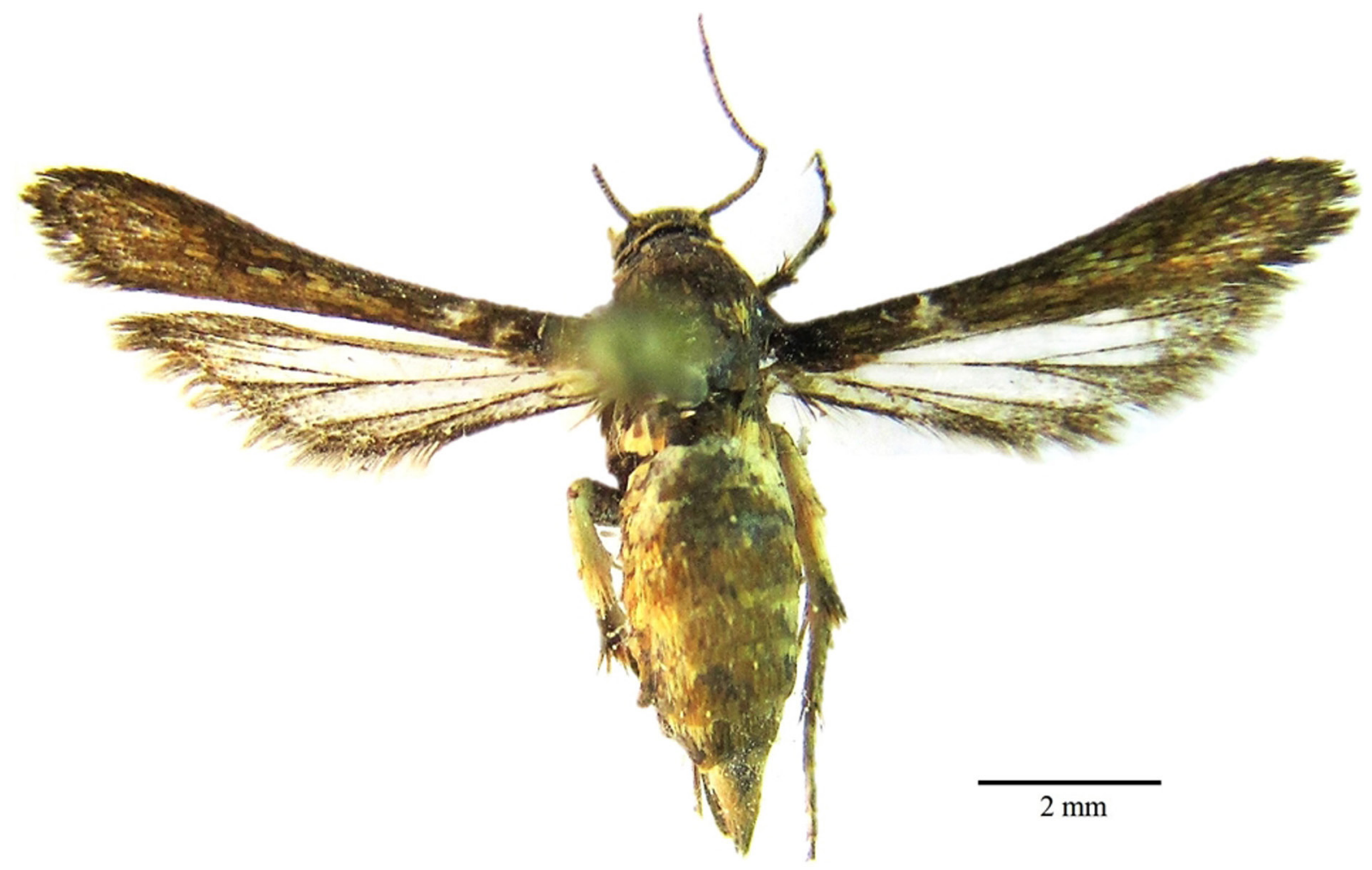

Figure 2. Dorsal photograph of Tinthia tineiformis (voucher ID SESDM001) collected from Malta.

on a $1.5 \%$ agarose gel stained with ethidium bromide, together with a $100 \mathrm{bp}$ DNA ladder (Solis BioDyne, Estonia). Each of the remaining PCR product was subsequently purified and sequenced in both directions with an ABI3730XL sequencer. Quality check, editing, and assembly of complementary barcode sequences was conducted in Geneious ${ }^{\circledR}$ 11.1.2 (https://www.geneious.com; Kearse et al. 2012). The final COI sequence of 619 bp was searched against NCBI GenBank ${ }^{\circledR}$ database (GenBank, https://www.ncbi.nlm.nih.gov/genbank; Benson et al. 2012) nucleotide collection (nr/nt) using BLASTn v. 2.9.0 (Zhang et al. 2000; Morgulis et al. 2008). The 619 bp sequence was also searched against the species level barcode records available at the Barcode of Life Data System (BOLD, http://www.boldsystems.org; Ratnasingham and Hebert 2007). The COI sequence data of the specimen was deposited to GenBank (MK803278).

\section{Results}

\section{Tinthia tineiformis (Esper, 1789)}

New records. Malta: Sigg giewi (3551'4"N, 014²5'31" E; 140 m a.s.1.), D. Magro leg., June 182018 (1 female, CBRG-UM, voucher ID SESDM001).

Identification. The genus of the specimen was identified as Tinthia Walker, 1865 and distinguished from a closely related genus, Pennisetia Dehne, 1850, due to the filiform antennae, the lack of transparent areas on the fore wings, and the hind wing vein pattern with $\mathrm{Cu}_{1}$ arising before crossvein (Fig. 2) (Laštůvka and Laštůvka 2001; Paolucci 2016). The species identity of the specimen was classified as T. tineiformis and was distinguished from other Tinthia species by absence of distinct yellow bands on abdomen, brown coloration of the fore wings and abdomen, the lack of orange coloration of the hind tibia, coloration of the first abdominal segment, and the lack of yellowish-white spots in the distal part of the fore wings (Fig. 2) (Laštůvka 1985; Laštůvka and Laštůvka 2001). The specimen was identified as a female based on the shape of abdomen and anal tuft, following Laštůvka (1985).

BLAST hit results of the 619 bp COI sequence from the specimen examined resulted in the highest pairwise identity of $99.8 \%$ to two sequences with the accession numbers AJ864349 and AJ864350 assigned to T. tineiformis in GenBank. The identification tool in BOLD assigned the sequence from our specimen to the BIN URI: BOLD: AAD9679 which corresponds to the species T. tineiformis. The assigned BIN intraspecific $p$-distance ranged from $0 \%$ to $0.78 \%$.

Observations. The specimen was found at 11 a.m. on a sunny day in an open area dominated by agricultural land and herbaceous vegetation along rural roadsides. The specimen was found resting on a sunlit stone wall, which had been cleared of vegetation prior to the discovery of the specimen. The plant remains from the location where the specimen was found were identified as Convolvulus spp. and Hedera helix L. Within the enclosure, the live specimen was observed using two different jumping strategies. One strategy was jumping and landing without opening the wings and a second strategy involved jumping for take-off and then transitioning into powered flight. 
For the newly recorded Maltese sesiid species, T. tineiformis, we propose the Maltese name "Bahrija Żunżan tas-Sejjieh". In Maltese "Sejjieh" refers to the stone used to construct rubble walls, which is the habitat where this species was first discovered in Malta.

\section{Discussion}

This first record of T. tineiformis from Malta at one location, despite the ongoing sampling efforts done by the authors, may suggest that this species has a restricted local distribution, a common characteristic among other sesiid species (Garrevoet et al. 2005, 2015). In Sicily, $T$. tineiformis was recorded from multiple locations (Bella et al. 2017); therefore, further research may elucidate the distribution of T. tineiformis in Malta and be able to confirm whether the species is localized and to assess the conservation status of this taxon in the Maltese Islands. Tinthia brosiformis (Hubner, 1813), a species closely related to T. tineiformis, is a widespread species in Turkey and both related taxa depend on the same host plants, Convolvulus spp. (Garrevoet et al. 2005). Convolvulus spp. are widespread in the Maltese Islands (Weber and Kendzior 2006) and may therefore serve as indicators of suitable habitat for T. tineiformis.

The discovery of an individual of $T$. tineiformis occurred after the wall where it was found had been cleared of roadside vegetation which included bindweeds (Convolvulus spp.) and the Common Ivy (Hedera helix). The larvae of Tinthia spp. are known to live inside roots of Convolvulus spp. (Bertaccini and Fiumi 2002; Garrevoet et al. 2005), and our results might support this observation. The habitat was modified by roadworks before the specimen was found and only plant remains were recovered from the location. Therefore, the hostplant association could not be ascertained. Due to the colonial behavior documented for many sesiid species (Garrevoet et al. 2005), the removal of vegetation from roadsides, especially in rural areas, could have a substantial detrimental impact on the population of this species in Malta.

Observations of the specimen within an enclosure revealed that $T$. tineiformis uses two different jumping strategies. These behavioral adaptations might allow faster escape from predators and provide the necessary propulsive force for take-off (Burrows and Dorosenko 2015). Such behavior could partially explain why this species was never recorded in Malta before now. We are not aware of previous published data suggesting this behavior for T. tineiformis. However, the two jumping strategies observed and described are common for other small species of Lepidoptera (Burrows and Dorosenko 2015).

The DNA barcoding approach assists in the taxonomy of sesiid species (Hansen et al. 2012; Garrevoet et al. 2013) and contributes towards the formulation of their conservation and management plans (Lait and Hebert 2018). Such a molecular technique is highly valuable if included as a routine process when documenting the presence of taxa across their geographical range. Despite the small area of the Maltese Islands, new insect records are still made frequently, which indicates that the knowledge on insect biodiversity is still progressing. Ongoing field research accompanied by DNA barcoding of tissues from insect specimens sampled by us is helping to fill these knowledge gaps in order to provide an essential baseline for biodiversity conservation.

\section{Acknowledgements}

This study was partially funded by the BioCon_Innovate Research Fund from the University of Malta. We would like to thank 3 anonymous reviewers and the editors for their constructive comments and suggestions on earlier versions of the manuscript.

\section{Authors' Contributions}

$\mathrm{AV}$ and CMM assessed the location and habitat features associated with the specimen under investigation, undertook the morphological and genetic data analyses and prepared the manuscript; DM observed and captured the live specimen and pinned the specimen in preparation for morphological analyses after taking records of its behavioral characteristics.

\section{References}

Bąkowski M, Hołowiński M (2010) Morphology, biology and distribution of Chamaesphecia nigrifrons (Le Cerf, 1911) (Lepidoptera: Sesiidae) in Poland. Polish Journal of Entomology 79 (2): 203-210.

Bąkowski M, Ulrich W, Laštůvka Z (2010) Environmental correlates of species richness of Sesiidae (Lepidoptera) in Europe. European Journal of Entomology 107 (4): 563-570. https://doi.org/10.14411/ eje. 2010.065

Bella S, Bartsch D, Laštůvka Z (2017) Bibliographic summary and new records of the Brachodidae and Sesiidae of Sicily, with an updated list and some comments on the distribution of Italian species (Lepidoptera, Cossoidea). Spixiana 40 (1): 139-156.

Benson DA, Cavanaugh M, Clark K, Karsch-Mizrachi I, Lipman DJ, Ostell J, Sayers EW (2012) GenBank. Nucleic Acids Research 41 (D1): D36-D42. https://doi.org/10.1093/nar/gks1195

Bertaccini E, Fiumi G (2002) Bombici and Sfingi d'Italia (Lepidoptera: Sesioidea) Volume IV. Filograf, Forli, 181 pp.

Burrows M, Dorosenko M (2015) Jumping mechanisms and strategies in moths (Lepidoptera). Journal of Experimental Biology 218 (11): 1655-1666. https://doi.org/10.1242/jeb.120741

Duckworth WD, Eichlin TD (1974) Clearwing Moths of Australia and New Zealand (Lepidoptera: Sesiidae). Smithsonian Institution Press, Washington, DC, 45 pp.

Garrevoet T, Garrevoet W, Özbek H (2005) A contribution to the knowledge of the Sesiidae of Turkey (Lepidoptera). Turkish Journal of Zoology 29 (1): 27-38.

Garrevoet T, Garrevoet W, Özbek H (2007) Data on the geographic distribution of Sesiidae (Lepidoptera) in Turkey. Linzer biologische Beiträge 39 (2): 929-953.

Garrevoet T, Bartsch D, Lingenhöle A (2013) On the knowledge of Bembecia rushana Gorbunov, 1992 and some related species (Lepidoptera: Sesiidae). Nota Lepidopterologica 36 (2): 95-108.

Garrevoet T, Garrevoet J, Garrevoet W (2015) On the knowledge of Bembecia hofmanni with description of the female (Lepidoptera: 
Sesiidae). Phegea 43 (2): 26-30.

Gorbunov OG, Efetov KA (2018) The clearwing moth genus Bembecia Hübner 1819 ['1816'] (Lepidoptera, Sesiidae) in Crimea, with the description of a new species. Zoologicheskiu Zhurnal 97 (7): 812-839. https://doi.org/10.1134/s0044513418070085

Hansen JA, Klingeman WE, Moulton JK, Oliver JB, Windham MT, Zhang A, Trigiano RN (2012) Molecular identification of Synanthedonini members (Lepidoptera: Sesiidae) using Cytochrome Oxidase I. Annals of the Entomological Society of America 105 (4): 520-528. https://doi.org/10.1603/an11028

Hebert PDN, Penton EH, Burns JM, Janzen DH, Hallwachs W (2004) Ten species in one: DNA barcoding reveals cryptic species in the neotropical skipper butterfly Astraptes fulgerator. Proceedings of the National Academy of Sciences 101 (41): 14812-14817. https:// doi.org/10.1073/pnas.0406166101

Heppner JB, Duckworth WD (1981) Classification of the superfamily Sesioidea (Lepidoptera:Ditrysia). Smithsonian Contributions to Zoology 314: 1-144. https://oi.org/10.5479/si.00810282.314

Kallies A, Pühringer F (2004) Provisional checklist of the Sesiidae of the world (Lepidoptera: Ditrysia). Mitteilungen der Entomologischen Arbeitsgemeinschaft Salzkammergut 4:1-85.

Karimpour Y, Fathipour Y, Talebi AA, Moharramipour S (2007) Biology of Chamaesphecia schizoceriformis (Lep.: Sesiidae), a biocontrol agent of Euphorbia boissieriana (Euphoribiales: Euphoribiaceae) in north west of Iran. Journal of Entomological Society of Iran 26 (2): 35-45.

Karsholt O, van Nieukerken EJ (2013) Lepidoptera, Moths. Fauna Europaea, version 2017.06. https://fauna-eu.org/. Accessed on: 2019-4-14.

Kearse M, Moir R, Wilson A, Stones-Havas S, Cheung M, Sturrock S, Buxton S, Cooper A, Markowitz S, Duran C, Thierer T, Ashton B, Meintjes P, Drummond A (2012) Geneious Basic: an integrated and extendable desktop software platform for the organization and analysis of sequence data. Bioinformatics 28 (12): 1647-1649. https://doi.org/10.1093/bioinformatics/bts199

Lait LA, Hebert PDN (2018) A survey of molecular diversity and population genetic structure in North American clearwing moths (Lepidoptera: Sesiidae) using cytochrome c oxidase I. PLoS ONE 13 (8): 1-16. https://doi.org/10.1371/journal.pone.0202281

Laštůvka Z (1985) On the taxonomy of Microsphecia tineiformis (Esper) and M. brosiformis (Hübner) (Lepidoptera, Sesiidae). Acta Universitatis Agriculturae et Silviculturae Mendelianae Brunensis 33 (2263): 183-190.

Laštůvka Z, Laštůvka A (2001) The Sesiidae of Europe. Apollo Books, Stenstrup, 245 pp.

Levi-Zada A, Ben-Yehuda S, Dunkelblum E, Gindin G, Fefer D,
Protasov A, Kuznetsowa T, Manulis-Sasson S, Mendel Z (2011) Identification and field bioassays of the sex pheromone of the yellow-legged clearwing Synanthedon vespiformis (Lepidoptera: Sesiidae). Chemoecology 21 (4): 227-233. https://doi.org/10.1007/ s00049-011-0081-7

McKern JA, Szalanski AL, Johnson DT, Dowling APG (2008) Molecular phylogeny of Sesiidae (Lepidoptera) inferred from mitochondrial DNA sequences. Journal of Agricultural and Urban Entomology 25 (3): 165-177. https://doi.org/10.3954/15235475-25.3.165

Morgulis A, Coulouris G, Raytselis Y, Madden TL, Agarwala R, Schäffer AA (2008) Database indexing for production MegaBLAST searches. Bioinformatics 24 (16): 1757-1764. https://doi. org/10.1093/bioinformatics/btn322

Naka H, Horie Y, Mochizuki F, Vang LV, Yamamoto M, Saito T, Watarai T, Tsuchida K, Arita Y, Ando T (2008) Identification of the sex pheromone secreted by Synanthedon hector (Lepidoptera: Sesiidae). Applied Entomology and Zoology 43 (4): 467-474. https://doi.org/10.1303/aez.2008.467

Naumann CM (1971) Untersuchungen zur Systematic und Phylogenese der holarktischen Sesiiden (Insecta, Lepidoptera). Bonner Zoologische Monagraphien 1: 1-190.

Paolucci P (2016) Bombyces and Sphinges of the Alps and their Larvae, Pupae and Cocoons. WBA Handbooks 6. World Biodiversity Association, Verona, $560 \mathrm{pp}$.

Ratnasingham S, Hebert PDN (2007) BOLD: The Barcode of Life Data System (www.barcodinglife.org). Molecular Ecology Notes 7 (3): 355-364. https://doi.org/10.1111/j.1471-8286.2006.01678.x

Skowron M, Munisamy B, Hamid S, Wegrzyn G (2015) A new species of clearwing moth (Lepidoptera: Sesiidae: Osminiini) from Peninsular Malaysia, exhibiting bee-like morphology and behaviour. Zootaxa 4032 (4): 426-434. https://doi.org/10.11646/ zootaxa.4032.4.7

Skowron Volponi MA, McLean DJ, Volponi P, Dudley R (2018) Moving like a model: mimicry of hymenopteran flight trajectories by clearwing moths of Southeast Asian rainforests. Biology Letters 14 (5): 1-6. https://doi.org/10.1098/rsbl.2018.0152

Špatenka K, Gorbunov O, Laštůvka Z, Toševski I, Arita Y (1999) Handbook of Palaearctic Macrolepidoptera. Vol. 1. SesiidaeClearwing Moths. Gem Publishing Company, Wallingford, xv + 569 pp.

Weber H, Kendzior B (2006) Flora of the Maltese Islands: a Field Guide. Margraf Publishers, Weikersheim, 383 pp.

Zhang Z, Schwartz S, Wagner L, Miller W (2000) A greedy algorithm for aligning DNA sequences. Journal of Computational Biology 7 (1-2): 203-214. https://doi.org/10.1089/10665270050081478 